\title{
Original
}

\section{Genetic polymorphism of MUC7 in individuals with aggressive or chronic periodontitis}

\author{
Giselle P. Gomes, Marina A. L. Assis, Juliana S. S. Fonseca, Paulo E. A. de Souza, \\ Elton G. Zenóbio, Dauro D. Oliveira and Rodrigo V. Soares \\ Department of Dentistry, Pontiphical Catholic University of Minas Gerais, Belo Horizonte, MG, Brazil
}

(Received 6 May and accepted 15 September 2011)

\begin{abstract}
Individuals with periodontitis exhibit differential expression of mucin-glycoprotein-2 (MG2), a protein encoded by the MUC7 gene. It is well known that MG2 exerts bactericidal activity as well as exhibiting genetic polymorphism involving a variable number of tandem repeats (VNTR). In the present study, we assessed the distribution of allelic variants of the MUC7 gene in 22 individuals with aggressive periodonitis, 68 with chronic periodonitis, and 87 without periodonitis. Oral mucosal cells were collected, the DNA was extracted, and specific primers were used to amplify the region encoding the MUC7 tandem repeats (TRs). Polymerase chain reaction products were subjected to electrophoresis and analyzed on polyacrylamide gels stained with silver nitrate. Although the percentage distribution of homozygosity (6-6TR) and heterozygosity (5-6TR) showed variation among the groups, the observed differences were not statistically significant $(P>0.05$; Fisher's Exact Test). The present results indicate that the expression of different numbers of TRs in this salivary mucin in the oral environment does not interfere with the etiopathogenesis of aggressive or chronic periodontitis. (J Oral Sci 53, 445-449, 2011)
\end{abstract}

Keywords: periodontitis; gene polymorphism; salivary mucin; MUC7.

Correspondence to Dr. Rodrigo Villamarim Soares, Programa de Mestrado em Odontologia - Prédio 46, Pontifícia Universidade Católica de Minas Gerais, Av. Dom José Gaspar, 500 - Coração Eucarístico, Belo Horizonte, MG, 30315-480, Brazil

Tel: $+55-31-3319-4414$

Fax: +55-31-3319-4415

E-mail: soaresrv@pucminas.br

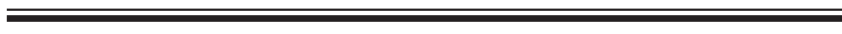 \\ Introduction}

Periodontal disease is an inflammatory reaction of periodontal tissues in response to infection caused by a specific group of bacteria (1). Aggressive periodontitis is characterized by severe and rapid loss of periodontal attachment, often commencing at or after the circumpubertal age, and chronic periodontitis is a common disease prevalent among adults and seniors $(2,3)$. Studies investigating genetic factors that might contribute to the development of aggressive and chronic periodontitis are necessary in order to improve existing knowledge of multigenetic predisposition to these diseases (4). In this connection, recent reports have confirmed associations between specific polymorphic variants of the Fc gamma receptor (5), toll-like receptor (6), interleukin-1 (7) and human leukocyte antigens (8) with aggressive and/or chronic periodontitis.

The MUC7 gene product, a soluble $180-\mathrm{kDa}$ salivary mucin named MG2, is well recognized as a key component of the oral host defense system. MUC7 is also known to display genetic polymorphism that generates a variable number of tandem repeat (VNTR) domains (9). MUC7 typically encodes 6 heavily glycosylated tandem repeats (TRs) (10), each with 23 amino acids, and polymorphism encoding 5-TR has been associated with a decreased risk of being asthmatic $(11,12)$, as well as conferring a protective effect on respiratory function (13).

It has been reported that MG2 is present in the pellicle formed on cementum surfaces (14), that it exhibits candidacidal activity (15), kills the periodontal pathogen Aggregatibacter actinomycetemcomitans (16), and forms heterotypic complexes with specific salivary proteins in the oral environment $(17,18)$. A previous study has 
shown that MG2 output in individuals with aggressive periodontitis was decreased by a factor of at least three in comparison with periodontal healthy subjects, suggesting a decline in mucin defence, and consequently a higher susceptibility to oral infections (19).

Several studies have reported that oligosaccharide moieties present on mucins act as attachment sites for bacteria and viruses (20-23). Furthermore, alterations of mucin glycosylation patterns affect their ability to adhere to, or recognize, antigens or microorganisms (24), or to aggregate viruses via their sugar chains (25). Since MUC7 TRs are heavily glycosylated (10), we can hypothesize that in principle the expression of 5 or 6 TRs could alter the distinct functions of this salivary mucin in the oral environment. Therefore, the present study was conducted to analyze the distribution of MUC7 allelic variants in individuals with aggressive and chronic periodontitis.

\section{Materials and Methods \\ Study population}

This study employed a cross-sectional design involving individuals from the State of Minas Gerais in the southeastern region of Brazil. It is important to emphasize that individuals were not stratified according to ethnic groups based on skin color, race or geographic origin due to the strong miscegenation among Brazilians (26). Exclusion criteria included: recent (3 months) use of antibiotics, use of orthodontic appliances, chronic usage of anti-inflammatory drugs, diabetes, infection with hepatitis or human immunodeficiency virus, use of immunosuppressive chemotherapy, presence of bleeding disorders, severely compromised immune function, and/ or pregnancy.

Participants received a complete periodontal examination, including assessment of probing depth in six sites per tooth (mesiobuccal, midbuccal, distobuccal, distolingual, midlingual and mesiolingual), probing attachment level and recession, evaluation of bleeding and/or suppuration on probing, radiographic examination, and complete anamnesis. Specific inclusion criteria were used to stratify the participants into three groups, based on previous studies (2,27-29). Participants needed to meet the following criteria in order to be included in this study:

\section{Aggressive periodontitis:}

- localized aggressive periodontitis: periodontal damage localized to permanent first molars and incisors

- generalized aggressive periodontitis: generalized interproximal attachment loss affecting at least 3 permanent teeth other than the permanent first molars and incisors

- clinical attachment loss $(\mathrm{CAL}) \geq 5 \mathrm{~mm}$; probing depth $\geq 6 \mathrm{~mm}$

Generalized chronic periodontitis:

- more than $30 \%$ of sites involved

- moderate: CAL 3-4 mm; probing depth 4-6 mm

- severe: (IV) CAL $\geq 5 \mathrm{~mm}$; probing depth $\geq 6 \mathrm{~mm}$ Control group: probing depth $<4 \mathrm{~mm}$ at all sites

On this basis, a total of 177 individuals receiving treatment at the School of Dentistry, Pontiphical Catholic University of Minas Gerais, were included. The participants came from the same geographical area, had a similar socio-economic status, and displayed no significant differences in the ratio of men to women among groups. As expected (30), individuals with aggressive periodontitis were distributed within a younger and narrower age range (18-28 yr) than individuals with chronic periodontitis or those without periodontitis (27-55 yr and 19-51 yr, respectively). The study was independently reviewed and approved by the Research Ethics Committee of the Pontiphical Catholic University of Minas Gerais. Informed consent was obtained from all individuals prior to their participation, and subjects' rights were protected at all times.

\section{DNA extraction and amplification of MUC7 fragments}

Epithelial cells were obtained by scraping the oral mucosa with the tip of a sterile spatula, which was then immediately immersed in a 2-ml sterile microtube containing $1.5 \mathrm{ml}$ of Krebs buffer $(7.25 \mathrm{~g} / \mathrm{L} \mathrm{NaCl}, 0.30$ $\mathrm{g} / \mathrm{L} \mathrm{KCl}, 2 \% \mathrm{CaCl}_{2}, 2 \% \mathrm{H}_{2} \mathrm{O}, 0.29 \mathrm{~g} / \mathrm{L} \mathrm{MgSO}_{4}, 5.95$ $\mathrm{g} / \mathrm{L} \mathrm{KH}_{2} \mathrm{PO}_{4}, 1.80 \mathrm{~g} / \mathrm{L}$ glucose). DNA extraction was performed as described previously (31). Briefly, a pellet of epithelial cells was obtained by centrifugation at $200 \mathrm{x}$ g for $5 \mathrm{~min}$. The supernatant was removed, and $20 \mu 1$ of silica ( $\mathrm{SiO}_{2}$; Sigma, St Louis, MO, USA) and $450 \mu 1$ of lysis buffer ( $6.0 \mathrm{M}$ Guanidine Thiocyanate, 65 $\mathrm{mM}$ Tris- $\mathrm{HCl}, \mathrm{pH}$ 6.4, 25 mM EDTA and 1.5\% Triton $\mathrm{X}-100)$ were added to the microtubes. Samples were homogenized, incubated for $30 \mathrm{~min}$ at $56^{\circ} \mathrm{C}$, subjected to further centrifugation, and the resulting supernatant was discarded. The pellet obtained was washed twice with $450 \mu \mathrm{l}$ of washing buffer $(6.0 \mathrm{M}$ GuSCN, $65 \mathrm{mM}$ Tris$\mathrm{HCl}, \mathrm{pH}$ 6.4), twice with $450 \mu \mathrm{l}$ of $70 \%$ ethanol, once with $450 \mu \mathrm{l}$ of acetone, and dried at $56^{\circ} \mathrm{C}$ for $20 \mathrm{~min}$. Finally, $100 \mu \mathrm{l}$ of TE buffer (10 mM Tris-HCl, pH 8.0, and $1 \mathrm{mM}$ EDTA) was added, followed by incubation at $56^{\circ} \mathrm{C}$ for $12 \mathrm{~h}$ to release the DNA. After incubation, the solution was homogenized, centrifuged, and the supernatant containing DNA was transferred to a new tube. 


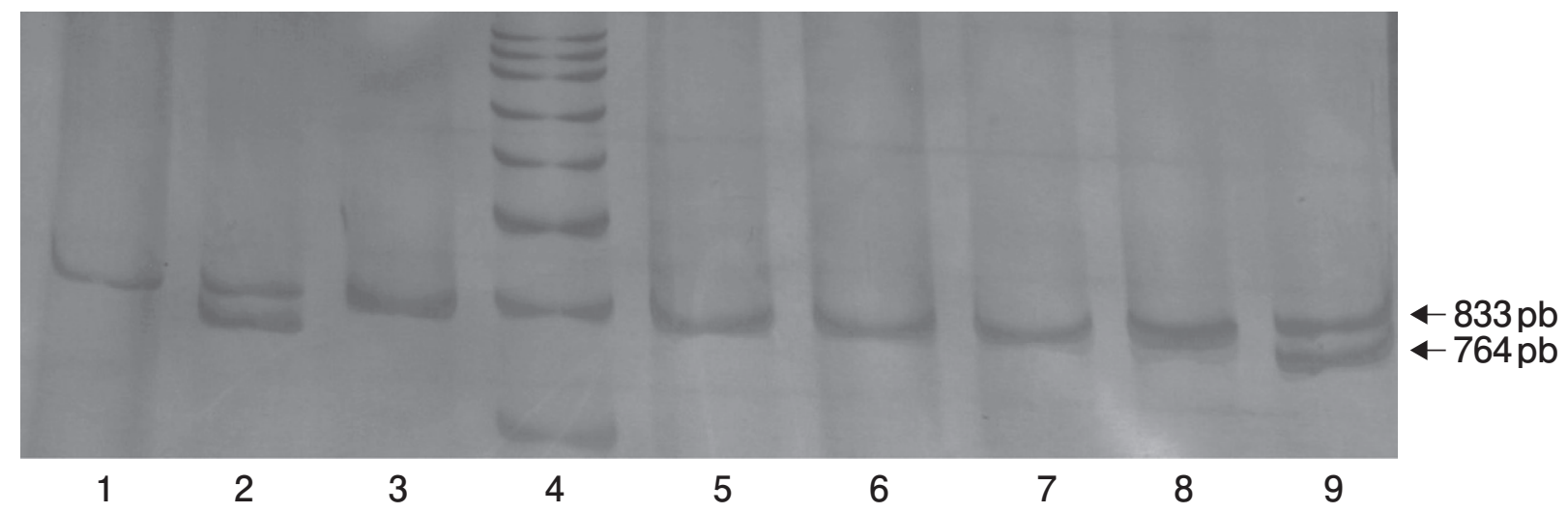

Fig. 1 Polyacrylamide gel of PCR products showing the allelic length variation of MUC7. Lanes 1, 3, 5-8: homozygous MUC7 6-6; lanes 2 and 9: heterozygous MUC7 5-6; lane 4: 200 bp DNA ladder; bp: base pairs

Table 1 Frequencies of MUC7 5-6 and 6-6 TR

\begin{tabular}{cccc}
\hline & Aggressive periodontitis & Chronic periodontitis & Control \\
\hline Number of individuals & 22 & 68 & 87 \\
$5-6$ & $5(22.7 \%)$ & $8(11.8 \%)$ & $15(17.2 \%)$ \\
$6-6$ & $17(77.3 \%)$ & $60(88.2 \%)$ & $72(82.8 \%)$ \\
\hline
\end{tabular}

Statistically significant differences between groups were not observed ( $P>0.05$ for all analysis; Fisher's exact test), TR: Tandem repeats, Control: individuals without periodontitis.

PCR primers and assay conditions described below were developed in the present study. The sequences of the PCR primers employed were $5^{\prime}$-ggtcaaccetaccttagtg-3' and 5'-ttgctccaccatgtcgtcaa-3'. PCR was carried out in a total volume of $50 \mu 1$, containing $10 \mu \mathrm{l}$ of DNA solution, premix buffer $(50 \mathrm{mM} \mathrm{KCl}, 10 \mathrm{mM}$ Tris- $\mathrm{HCl}, \mathrm{pH} 8.4$, $0.1 \%$ Triton X-100, $1.5 \mathrm{mM} \mathrm{MgCl}_{2}$, deoxynucleoside triphosphates, and Taq DNA polymerase) and primers (10 pmol per reaction). The PCR parameters were: $94^{\circ} \mathrm{C}$ for $3 \mathrm{~min}, 35$ cycles of $94^{\circ} \mathrm{C}$ for $30 \mathrm{~s}, 64^{\circ} \mathrm{C}$ for $30 \mathrm{~s}$, and $72^{\circ} \mathrm{C}$ for $1 \mathrm{~min}$, with a final extension step at $72^{\circ} \mathrm{C}$ for 5 min. The PCR products were electrophoresed on $6.5 \%$ polyacrylamide gels and subsequently stained with silver nitrate. Molecular diagnosis was determined according to the size of the obtained fragments (833 bp - 6 TR; 764 bp - 5 TR).

\section{Statistical analysis}

Fisher's exact test was used to compare the distributions of genotypes between groups. The significance level was set at 0.05 , and analysis was performed using the statistical program Statview 4.5 (Abacus Concepts Inc., Berkeley, California, USA).

\section{Results}

Analysis of the products amplified from the MUC7 gene containing the region encoding the MUC7 TR was performed on polyacrylamide gels stained with silver nitrate, and a representative gel is shown in Figure 1. The distribution of MUC7 alleles in individuals from each of the groups is indicated in Table 1. In 149 individuals (84\%), both alleles had $6 \mathrm{TR}$, and in the remaining 28 subjects $(16 \%)$ one allele had 6 TR and the other had 5 TR. The proportion of homozygotes (6-6 TR) was $77.3 \%$ in individuals with aggressive periodontitis, $88.2 \%$ in individuals with chronic periodontitis, and $82.8 \%$ in individuals without periodontitis. Consequently the corresponding proportions of heterozygotes (5-6 TR) were $22.7 \%, 11.8 \%$ and $17.2 \%$, respectively. There were no significant differences in the distribution of homozygotes and heterozygotes between the groups (Fisher's Correlation $P>0.05$ for all analyses).

\section{Discussion}

The salivary mucin MG2 is encoded by the MUC7 gene. MG2 is expressed in salivary secretions derived from the submandibular, sublingual and minor salivary glands (17). MG2 is composed of 357 amino acids that 
are located in 5 distinct regions: (A) an $\mathrm{N}$-terminal region containing the only two cysteines in the molecule and a leucine-zipper segment, (B) a moderately glycosylated domain, (C) a heavily glycosylated region containing five or six 23-residue TRs, (D) a second heavily glycosylated region, and (E) a C-terminal leucine zipper segment (10).

Since oligosaccharides present on mucins act as receptors for microorganisms (20-25), it is possible that the adhesion and/or aggregation of periodontopathogens by this salivary mucin occurs at the TR region. Additionally, the loss of 23 amino acids could, in principle, have an effect on the conformation of the MUC7 molecule, which is likely to influence its function $(10,32)$. Therefore, the present study was undertaken to compare the distribution of MUC7 alleles between subjects with aggressive periodontitis, chronic periodontitis or lacking periodontitis, in order to determine whether the presence of specific alleles and, consequently, the expression of a protein with 5 or 6 TR could be correlated with aggressive and/ or chronic periodontitis.

We observed a reduced person-to-person sequence variation within the tandem repeat array. These results revealed that the allele encoding the 6 TR was predominant among the groups, a finding that has also been reported previously (11-13). Although differences in the genotype percentages of 5-6 TR (aggressive periodontitis 22.7\%; chronic periodontitis $11.7 \%$; control $17.2 \%$ ) and 6-6TR (aggressive periodontitis 77.2\%; chronic periodontitis $88.2 \%$; control $82.7 \%$ ) were observed, this variation was not statistically significant. This lack of correlation suggests that expression of 5 or 6 TR by this salivary mucin, at least in the context of periodontitis, does not adversely affect the protective role of MG2 in the oral cavity.

Some polymorphisms alter the expression and function of genes, affecting phenotypes and leading to disease susceptibility (33). Specific forms of genes can produce variations in tissue structure, the adaptive immune response, and the expression of inflammatory mediators. However, while the effects of some allelic variants may have clinical significance, those of others, such as MUC7 in the present study, have minimal or no significance (34). Periodontitis is a complex disease, and therefore further studies investigating the role of specific genetic factors in its etiopathogenesis should be conducted.

\section{Acknowledgments}

The present study was supported by FAPEMIG Grants EDT 447-07 and PPM 261-08.

\section{References}

1. Beck JD, Offenbacher S (1998) Oral health and systemic disease: periodontitis and cardiovascular disease. J Dent Educ 62, 859-870.

2. Armitage GC (1999) Development of a classification system for periodontal diseases and conditions. Ann Periodontol 4, 1-6.

3. Flemmig TF (1999) Periodontitis. Ann Periodontol 4, 32-38.

4. Armitage GC; Research, Science and Therapy Committee of the American Academy of Periodontology (2003) Diagnosis of periodontal diseases. J Periodontol 74, 1237-1247.

5. Dimou NL, Nikolopoulos GK, Hamodrakas SJ, Bagos PG (2010) Fcgamma receptor polymorphisms and their association with periodontal disease: a meta-analysis. J Clin Periodontol 37, 255-265.

6. Ozturk A, Vieira AR (2009) TLR4 as a risk factor for periodontal disease: a reappraisal. J Clin Periodontol 36, 279-286.

7. Nikolopoulos GK, Dimou NL, Hamodrakas SJ, Bagos PG (2008) Cytokine gene polymorphisms in periodontal disease: a meta-analysis of 53 studies including 4178 cases and 4590 controls. J Clin Periodontol 35, 754-767.

8. Stein JM, Machulla HK, Smeets R, Lampert F, Reichert S (2008) Human leukocyte antigen polymorphism in chronic and aggressive periodontitis among Caucasians: a meta-analysis. J Clin Periodontol 35, 183-192.

9. Biesbrock AR, Bobek LA, Levine MJ (1997) MUC7 gene expression and genetic polymorphism. Glycoconj J 14, 415-422.

10. Gururaja TL, Ramasubbu N, Venugopalan P, Reddy MS, Ramalingam K, Levine MJ (1998) Structural features of human salivary mucin, MUC7. Glycoconj J 15, 457-467.

11. Kirkbride HJ, Bolscher JG, Nazmi K, Vinall LE, Nash MW, Moss FM, Mitchell DM, Swallow DM (2001) Genetic polymorphism of MUC7: allele frequencies and association with asthma. Eur $\mathrm{J}$ Hum Genet 9, 347-354.

12. Watson AM, Ngor WM, Gordish-Dressman H, Freishtat RJ, Rose MC (2009) MUC7 polymorphisms are associated with a decreased risk of a diagnosis of asthma in an African American population. J Investig Med 57, 882-886.

13. Rousseau K, Vinall LE, Butterworth SL, Hardy RJ, Holloway J, Wadsworth ME, Swallow DM (2006) MUC7 haplotype analysis: results from a 
longitudinal birth cohort support protective effect of the MUC7*5 allele on respiratory function. Ann Hum Genet 70, 417-427.

14. Fisher SJ, Prakobphol A, Kajisa L, Murray PA (1987) External radiolabelling of components of pellicle on human enamel and cementum. Arch Oral Biol 32, 509-517.

15. Liu B, Rayment SA, Gyurko C, Oppenheim FG, Offner GD, Troxler RF (2000) The recombinant $\mathrm{N}$-terminal region of human salivary mucin MG2 (MUC7) contains a binding domain for oral Streptococci and exhibits candidacidal activity. Biochem J 345, 557-564.

16. Liu B, Rayment SA, Soares RV, Oppenheim FG, Offner GD, Fives-Taylor P, Troxler RF (2002) Interaction of human salivary mucin MG2, its recombinant $\mathrm{N}$-terminal region and a synthetic peptide with Actinobacillus actinomycetemcomitans. J Periodontal Res 37, 416-424.

17. Soares RV, Liu B, Oppenheim FG, Offner GD, Troxler RF (2002) Structural characterisation of cysteines in a bacterial-binding motif of human salivary mucin MG2. Arch Oral Biol 47, 591-597.

18. Soares RV, Siqueira CC, Bruno LS, Oppenheim FG, Offner GD, Troxler RF (2003) MG2 and lactoferrin form a heterotypic complex in salivary secretions. J Dent Res 82, 471-475.

19. Groenink J, Walgreen-Weterings E, Nazmi K, Bolscher JG, Veerman EC, van Winkelhoff AJ, Nieuw Amerongen AV (1999) Salivary lactoferrin and low-Mr mucin MG2 in Actinobacillus actinomycetemcomitans-associated periodontitis. J Clin Periodontol 26, 269-275.

20. Veerman EC, Bank CM, Namavar F, Appelmelk BJ, Bolscher JG, Nieuw Amerongen AV (1997) Sulfated glycans on oral mucin as receptors for Helicobacter pylori. Glycobiology 7, 737-743.

21. Prakobphol A, Tangemann K, Rosen SD, Hoover CI, Leffler H, Fisher SJ (1999) Separate oligosaccharide determinants mediate interactions of the low-molecular-weight salivary mucin with neutrophils and bacteria. Biochemistry 38, 6817-6825.

22. Offner GD, Troxler RF (2000) Heterogeneity of high-molecular-weight human salivary mucins. Adv Dent Res 14, 69-75.

23. Prakobphol A, Borén T, Ma W, Zhixiang P, Fisher
SJ (2005) Highly glycosylated human salivary molecules present oligosaccharides that mediate adhesion of leukocytes and Helicobacter pylori. Biochemistry 44, 2216-2224.

24. Taylor KL, Mall AS, Barnard RA, Ho SB, Cruse JP (1998) Immunohistochemical detection of gastric mucin in normal and disease states. Oncol Res 10, 465-473.

25. Habte HH, de Beer C, Lotz ZE, Roux P, Mall AS (2010) Anti-HIV-1 activity of salivary MUC5B and MUC7 mucins from HIV patients with different CD4 counts. Virol J 7, 269.

26. Parra FC, Amado RC, Lambertucci JR, Rocha J, Antunes CM, Pena SD (2003) Color and genomic ancestry in Brazilians. Proc Natl Acad Sci U S A 100, 177-182.

27. American Academy of Periodontology (2000) Parameter on chronic periodontitis with slight to moderate loss of periodontal support. J Periodontol 71, 853-855.

28. American Academy of Periodontology (2000) Parameter on chronic periodontitis with advanced loss of periodontal support. J Periodontol 71, 856-858.

29. American Academy of Periodontology (2000) Parameter on aggressive periodontitis. J Periodontol 71, 867-869.

30. Tonetti MS, Mombelli A (1999) Early-onset periodontitis. Ann Periodontol 4, 39-53.

31. Boom R, Sol CJ, Salimans MM, Jansen CL, Wertheim-van Dillen PM, van der Noordaa J (1990) Rapid and simple method for purification of nucleic acids. J Clin Microbiol 28, 495-503.

32. Naganagowda GA, Gururaja TL, Satyanarayana J, Levine MJ (1999) NMR analysis of human salivary mucin (MUC7) derived O-linked model glycopeptides: comparison of structural features and carbohydrate-peptide interactions. J Pept Res 54, 290-310.

33. Greenstein G, Hart TC (2002) A critical assessment of interleukin-1 (IL-1) genotyping when used in a genetic susceptibility test for severe chronic periodontitis. J Periodontol 73, 231-247.

34. Kinane DF, Hart TC (2003) Genes and gene polymorphisms associated with periodontal disease. Crit Rev Oral Biol Med 14, 430-449. 